\title{
Female Identity in the Language of Space of the 19th Century Residential Architecture in Sarajevo
}

\author{
Erdin Salihović, Nermina Zagora* \\ Faculty of Architecture, University of Sarajevo, Sarajevo, Bosnia and Herzegovina
}

\author{
Citation: Salihović E, Zagora N. Female Identity in the Language of \\ Space of the 19th Century Residential Architecture in Sarajevo. SEE \\ Archit Des. $2016 \quad$ November 11; 2016:10026. \\ .3889/seejad.2016.10026 \\ Keywords: residential architecture; heritage; Bosnian house; interior \\ female identity; patriarchal culture. \\ Correspondence: Nermina Zagora. Faculty of Architecture, University of \\ Sarajevo, Sarajevo, Bosnia and Herzegovina. E-mail \\ nerminaz@af.unsa.ba \\ Received: 19-Sep-2016; Revised: 20-Oct-2016; Accepted: 28-Oct- \\ 2016; Published: 11-Nov-2016 \\ Copyright: ๑ 2016 Erdin Salihović, Nermina Zagora. This is an open- \\ access article distributed under the terms of the Creative Commons \\ Attribution License, which permits unrestricted use, distribution, and \\ reproduction in any medium, provided the original author and source are \\ Funding: This research did not receive any financial support. \\ Competing Interests: The author has declared that no competing \\ interests exist.
}

\begin{abstract}
The traditional architecture of Bosnia and Herzegovina echoes historical and cultural narratives of ancient Ottoman patriarchal society. The Oriental culture had specifically defined the way in which the gender roles in family and society were manifested in the domestic space, and vice versa, space itself was shaped according to the criterion of gender. While exploring the gender criterion of differentiation of space in the traditional Bosnian residential architecture, this paper will particularly focus on the link between female identity and the spatial characteristics of the traditional Bosnian house. Critical evaluation of elements and principles that compose the traditional model of residential space within its cultural and historical context will be followed by a contemporary insight and interpretation of its universal architectural meanings.
\end{abstract}

\section{Introduction}

The traditional residential architecture of Bosnia and Herzegovina from the Ottoman period can be associated with the phenomenon of dualism. This phenomenon can be recognised within the domestic space in binary oppositions of interior and exterior, private and public sphere, oriental and western culture, and, finally, in the relationship between female and male gender within the family and society. By focusing on the impact of gender roles in the organisation of space, this paper intends to step outside the extents of the existing research which has mainly related to general architectural, historical and sociocultural features, and thus create a new insight on the genderspace correlation in the architectural heritage of Bosnia and Herzegovina.

The need for an objective examination of the gender criterion of the division of the traditional space has emerged as a response to the shared preconceptions and controversies around the notion of female identity within the patriarchal society. The correlation between the role of women in the family and society and the design of the traditional space in the case of residential architecture during the later stages of the Ottoman period in Sarajevo will be viewed from a two-way perspective: "relationship between the role of gender in the discourse of space and the role of space in the discourse of gender." (Wigley 1996, 329 [1]) Therefore, this paper will explore the following thesis:

The role of women in a patriarchal society can be regarded as the key determining factor that defined the distinctive spatial organisation and interior design of the traditional residential space during the Ottoman rule in Sarajevo. The methodology used in this research included historical, correlative, observational and case-study methods, complemented by graphic/schematic illustrations and tables.

\section{Traditional home as an artefact of the patriarchal culture}

Before developing a detailed analysis of the particular features of the traditional Bosnian house, it is 
essential to start with a theoretical elaboration of the causal relationship between patriarchal worldview and the design of the residential space. Even though the notion of the social split between the public and private sphere of life is commonly associated with oriental cultures and traditions, the actual concept of the division of space according to the gender criterion originates from ancient times, going back to the very roots of the Western civilisation. In fact, the structure of the ancient Greek house - Oikos, which consisted of two parts, andron (male quarters) and gynaikeion (female quarters) (lan 1999, 306 [2]) may be regarded as an early instrument for steering the social interactions within the family as a basic unit of the society. The ancient idea of a gender-based spatial organisation was explained in the 5th century BC treatise Oeconomicus by the ancient philosopher Xenophon who declared: "as it seems to me the woman's nature is for indoor and the man's for outdoor occupations." (Wigley 1996, 334 [1])

Similarly, families in ancient Rome were typically organized in a hierarchical manner led by their male members acting as pater familias (heads of the family), but distinctly from the ancient Greek model, Roman women enjoyed more freedom of movement and rights of participation, not only within the domestic space but also in the public life of ancient states. Furthermore, the distinction between male and female character as the key determining factor in the organisation of the family and society, likewise in the design and use of the space, was further explained by the by the Renaissance Man Leon Battista Alberti in his work Della Famiglia: "The woman, as she remains locked up at home, should watch over things by staying at her post, by diligent care and watchfulness. The man should guard the woman, the house, and his family and country, but not by sitting still." (Wigley 1996, 334 [1])

Insights into origins of the patriarchal concepts of the residential space reveal the symbolism of the traditional family hierarchy along with the idea of a house as an instrument for supervision and control over the female members of the family by the male, or the "head of the family". In this sense, space can be regarded as a physical manifestation of the latter system of supervision, and as channels of separation of female and male gender within the family.

Analysis of ancient models of houses, which have significantly influenced many residential typologies from patriarchal societies throughout history, accentuates the cultural principle of differentiation of "feminine" and "masculine" space. The level of admission of space to only one or both genders is defined by architectural tools of permission or restriction of access. As their spatial concept was defined by particular cultural paradigms, traditional homes may be regarded as the artefacts of patriarchal culture.

Where to search for the origins of the concept of a culturally conditioned spatial organisation, which is principally, reflected in the division of space according to the gender roles in a family? Various sociological and anthropological researches typically associate interior spaces with female gender, often referring to anthropo-morphological and mythological analogies between the two: „An 'inside' space may generate connotations of maternal femininity (the womb, the home), but may also link to the enclosed, concealed space of secrecy (a box, room)." (Mulvey 1996, 56 [3]) As implied by this "double" analogy, interior spaces can be understood as physical representations of the female character. The spatial structure is, on the one hand, compared to the anatomical features of female gender, while on the other hand; it underlines the symbolism of mystery, as a link between enclosed spaces and the representation of female characters in mythology. Idea of mysteriousness, a feature attributed both to interior spaces and the character of a woman, is described by the film critic Laura Mulvey in her elaboration of the Pandora myth: „Ichnographically, the figure of a woman can be identified as Pandora by the presence of her box, and a box attracts and repels by association with Pandora." (Mulvey 1996, 58 [3]) Referring to psychoanalysis, film art and Bachelard's poetics of space, Mulvey suggests that the Pandora metaphor encompasses subjects of curiosity, dialectics of interior and exterior space, and finally, enigma, as a conceptual link between femininity and enclosed space.

Therefore, the concept of differentiation of space according to the criterion of gender reflects the worldview of the patriarchal culture, and in traditional homes, it is manifested in the separation of the public/masculine and private/feminine sphere, in a manner that often corresponds to the relationship of the exterior and interior space. Regardless of whether it was shaped by the patriarchal idea of supervision over the female members of the family, or it symbolically represented the mystique aura of the female gender, the principle of gender-based separation of space played a significant role in defining architectural heritage of Bosnia and Herzegovina. The following section of this paper will study the determinism between the named principle and the design language, elements and principles in the case of the traditional Bosnian house from the Ottoman period.

\section{Cultural determinism of gender roles in the traditional society of Bosnia and Herzegovina during the Ottoman period}

Cultural heritage from the Ottoman period in Bosnia and Herzegovina was a result of the process of injection of the spirit of Orient in the medieval pores of the Bosnian state, thus evolving into an original and 
layered aesthetic totality. This paper concentrates on the time period of the second half of the $19^{\text {th }}$ century, which represented one of the key thresholds in the historical trajectory of Bosnia and Herzegovina. The named epoch was marked by the struggle for the state autonomy, as well as the by the transition between the Ottoman and Austro-Hungarian rule, which was followed by the cultural exchange between the civilisation of the East and the West. The process of gradual assimilation and incorporation of Islamic oriental influences into the roots of the autochthonous Slavic culture lead to cultural stratification and heterogeneity that imbued all aspects of life. This kind of symbiotic relationship gave rise to an authentic tradition that organically expanded due to numerous influences of several religious beliefs in the farthest province of the Ottoman Empire.

According to the fundamental patriarchal principles of the oriental society, the leadership roles were attributed to the male gender, assigning the principal duties of economic sustenance and taking care of family members to men, which consequently defined their status in family and society. Religious rules infused with autochthonous customs had clearly defined the relationship between men and women, as well as the role of the family as the nucleus of social organisation and preservation of moral values. "Religious laws define the family as the most important factor in the preservation of the entire society, as the survival of the moral life as a whole depend significantly on the role of the family." (Younis 2007, 38 [4])

On the other hand, various interpretations of religious rules [,This type of gender theory ("The Theory of subordination") was constructed upon hierarchical and patriarchal interpretations of Qur'an and the practice of the prophet Muhammad saws (sunna), and assigned the women the secondary role in society. The theory was justified by referring to the act of creation of women, which implied a peculiar feminine and masculine nature, even though Qur'an never defined feminine and masculine nature, nor did it suggest the creation of woman from the awry rib". (Spahić-Šiljak, Ženska ljudska prava - islamska perspektiva 2011, 87 [5]) restricted the role of women in the domain of household, significantly limiting their social activities and public interactions. Therefore, such patriarchal interpretations of Islamic principles and the Sharia law have isolated and excluded women from public life, while at the same time focusing them on the private sphere, motherhood and everyday household obligations. (Spahić-Šiljak, Žene, religija i politika: Analiza utjecaja interperativnog religijskog naslijeđa Judaism, kršćanstva i islama na angažman žene u javnom životu i politici u $\mathrm{BiH} 2007,197$ [6]) Consequently, women were not obliged to take part in the domain of economic sustenance of the family, which is why their exclusive role was placed within the extents of their own house and garden, where they enjoyed authority and respect by all family members.
Since the residential architecture in Bosnia and Herzegovina developed in response to the social and cultural circumstances, the roles of women and men as defined by the religious laws were accordingly transposed into the architectural composition of the traditional home. In this understanding of life and distribution of marital roles in the family, the public sphere was associated with men, while the private sphere was connected to women and the intimacy of private life.

Synthesis of religion, tradition and customs produced a system of cultural values in Bosnia and Herzegovina that specifically prescribed the principle of gender segregation "separated, but equal" (SpahićŠiljak i Anić 2009, 172 [7]) and significantly affected the way in which the residential space was understood, shaped and utilised.

\section{Decoding architectural language of the traditional Bosnian house during the Ottoman period}

An insight into the historical background of the gender principle in the traditional society in Bosnia and Herzegovina is intended to contribute to a better understanding of how this cultural phenomenon was articulated in architectural heritage. The following sections of this paper will include an analysis of developmental phases of the traditional model of residential space, as well as an interpretation of architectural language on the selected representative case of a Bosnian house. Stratification and heterogeneity of residential culture in Bosnia and Herzegovina originate from a long process of fusion of oriental influences and elements of the autochthonous Slavic culture. Traditional architectural concepts from the ancient typology of rural Dinaric house, a single volume space organised around an open hearth. The original model was later transformed by the principle of organisation of polyvalent spaces adopted from the oriental nomadic tradition of life under the tent, which encompassed the rhythmical alteration of all everyday life activities.

A fusion of the two models has set up a design principle of central composition housing typology, organised around the interior courtyard, an element inherited from the oriental and Mediterranean cultures. In fact, the concept of stringing of spatial sequences along the semi-open porch called divanhana organised around the central space as the focal point originates from ancient Persian and Byzantine cultures. The development of residential culture in Bosnia and Herzegovina was significantly influenced by religion, which is why the Islamic system of values was infused in everyday family and social life during four centuries (from $15^{\text {th }}$ to $19^{\text {th }}$ century). 
There were two types of layout over the course of development of urban houses in $\mathrm{BiH}$. Houses with symmetrical layouts were developed under the influence of the Ottoman residential culture, while the asymmetrical typologies, often being constructed in phases, had evolved from the autochthonous Slavic heritage. Eastern philosophy and religion served as guidelines for further development of residential space, resulting in a more complex spatial structure of the basic corpus, with a separate spatial segment with a public character oriented towards the street.

According to Islamic religious views, intimacy of family life was located in the central nucleus of the house, which was connected to the interior courtyard as an integral part of the typical residential layout. This design criterion has yielded the conceptual separation of masculine and feminine residential areas of a traditional house. Gender principle of separation of interior space was applied in all houses disregarding the social status of the owners. However, it was remarkably evident in the houses of the wealthier families, in which both areas for men and women were accompanied by their corresponding courtyards.

An analysis of the traditional house in Bosnia and Herzegovina from the Ottoman period denotes the function of architectural elements and principles in splitting the public and private sphere of social life, as well as in defining the roles of men and women within the family. The following sections comprise of an interpretation of meanings and idiosyncrasies of architectural language of traditional houses, as a direct reflection of the gender principle of the division of space, under the influence of the cultural and religious system of values. Representative urban house from Sarajevo - Svrzo's house, built during the $18^{\text {th }}$ and $19^{\text {th }}$ centuries, was selected for the case study which will illustrate the key elements and principles that compose the distinctive architectural language of this building (Table 1).

Table 1: Case study: Svrzo's house, representative building of traditional residential architecture from the Ottoman period in Sarajevo

\begin{tabular}{|l|l|l|l|}
\hline & $\begin{array}{l}\text { Architectural } \\
\text { language/Composition }\end{array}$ & & Meanings/Qualities \\
\hline 1.ANALYSIS & $\begin{array}{l}\text { Elements } \\
\text { Form/Space/Equipment }\end{array}$ & \multirow{2}{*}{ 2.INTERPRETATION } & $\begin{array}{l}\text { Original/Sociocultural } \\
\text { meanings }\end{array}$ \\
\cline { 2 - 2 } & $\begin{array}{l}\text { Principles } \\
\text { Contrast/Balance/Rhythm/Network }\end{array}$ & & $\begin{array}{l}\text { Universal/Architectural } \\
\text { qualities }\end{array}$ \\
\hline
\end{tabular}

\section{Contrast: public and private sphere}

There are two distinctive features of the interior layout of traditional Bosnian houses. To begin with, each residential complex in urban areas of the epoch consisted of the typical spatial areas: the building, an interior courtyard and the garden. On the other hand, as mentioned previously, one of the primary guidelines of the patriarchal society during the
Ottoman period was the separation of the public and private sphere of life. In architectural language, this concept was expressed in the separation of the two main areas of the house: selamluk (public/men's quarters) oriented to the street and haremluk (private/women's quarters), oriented towards the garden or the orchard. The physical border between the public and private space is represented by the wall, an architectural element serving as a barrier and protection, keeping the women out of sight of the public, as well as marking a clear separation between private and public areas. The wall, surrounding the entire residential complex aims to protect the intimacy and privacy of the family life, while at the same time serves to limit the movement and participation of women in public life. Privacy of the women's quarters haremluk - was ensured by the Vilajet constitution, which strictly defined the way of construction in which the new buildings were to strictly avoid the views towards the spaces "dedicated to women" (Roskiewicz 1868,227 [8]) of the neighbouring houses.
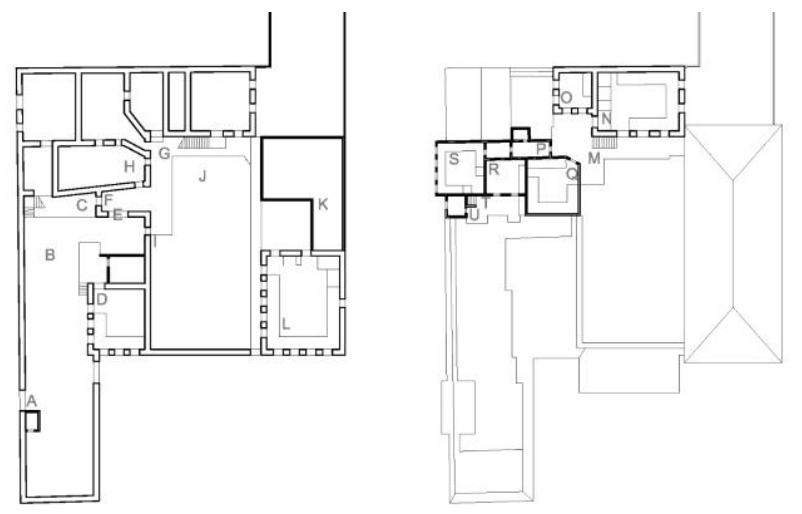

Figure 1: Svrzo's house floorplans. GROUND FLOOR: A. Main entrance; B. Selamluk (men's quarters); C. Men's Hajat; D. Men's halvat (room); E. Midlle gate (between selamluk and haremluk); F. Čekme-dolaf; G. Women's hajat; H. Kitchenette; I. Fountain; J. Haremluk (Women's quarters); K. Kitchen; L. Women's halvat. FIRST FLOOR: M. Women's divanhana; N. Halvat; O. Maiden's halvat; $P$. Mabejin (corridor connecting selamluk and haremluk)

Besides exterior garden walls, outlining the entire residential complex from the outside public space (the street), and those dividing two or more neighbouring parcels, there is a special wall typology the avlija wall - separating women's and men's courtyards and delineating selamluk from haremluk. The avlija wall bears the most important meaning in the context of the symbolism of gender segregation in the traditional Bosnian house.

The key role of the wall, as a dominant architectural element in the entire composition, lies in establishing a contrast between public and private space. Moreover, the omnipresence of walls is also largely responsible for the exterior appearance of the residential complex as simple and introvert, in contrast to its complex interior configuration. The resulting introverted form can be regarded as a metaphor of secrecy, whose interior reveals a special world of its 
own, reserved for women, at the same time protected and imprisoned, concealed from the public eye.

\section{Balance: exterior and interior space}

Contrary to the ascetic and withdrawn exterior appearance of traditional Bosnian houses, their interiors reveal the true spatial and ambient qualities. Moreover, one of the most important features of its architectural language is the balance between the building and its natural surroundings. A harmonic relationship of the house with its natural surroundings is manifested in an interaction of the building itself with its interior courtyards, as well as gardens and orchards. Wealthier families owned men's and women's interior courtyards, which were separated by a wall, as it was the case in the Svrzo's house. Interaction with nature was especially important due to the fact that the movement of the female members of the traditional family was restricted. Unlike the simple and modest appearances of men's avlija which belonged to selamluk, women's avlija represented the central nucleus of the house and served as focal point of the radial arrangement of the rooms which belonged to haremluk.

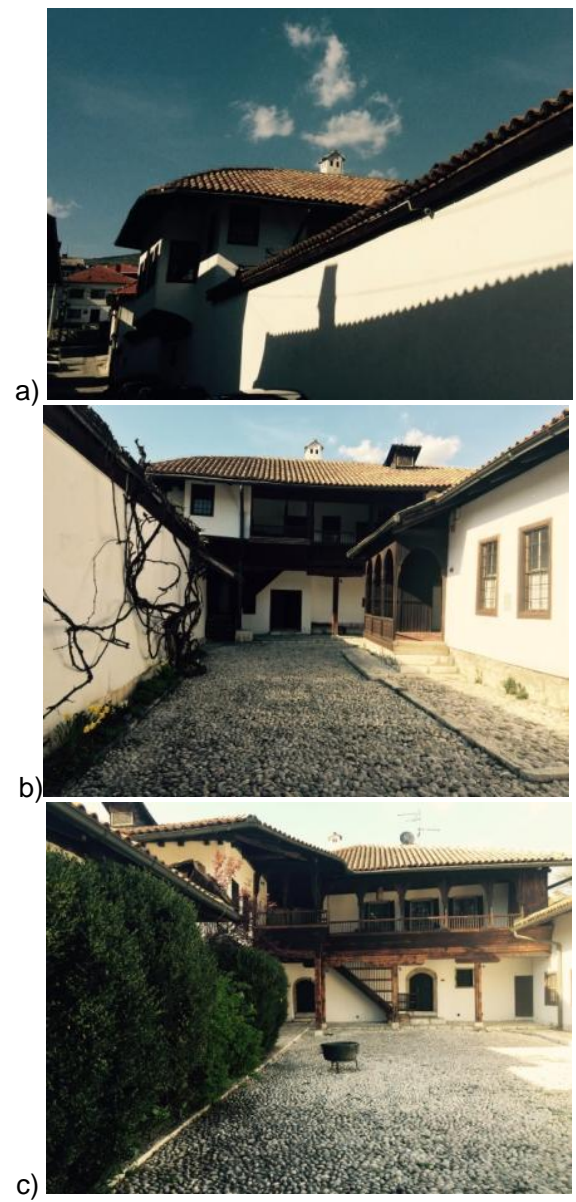

Figure 1: Svrzo's House, Sarajevo. a) Street view; b) Selamluk courtyard; b) Haremluk courtyard (from top to bottom)
The atmosphere of women's courtyards represents not only the visual but also the multisensory culmination of all spatial sequences of the houses, recalling a delicately laid-out oasis, paved with rounded cobble stone, outlined by simple white walls, complemented with the scent of flowers and the burble of water from the fountains. The principle of balance in the traditional Bosnian house can be identified in a harmonic correlation between exterior and interior space and is reflected in the correspondence between the house, courtyard and garden. Another example of the principle of balance is recognised on the human scale as the actual basis for proportioning of the entire composition.
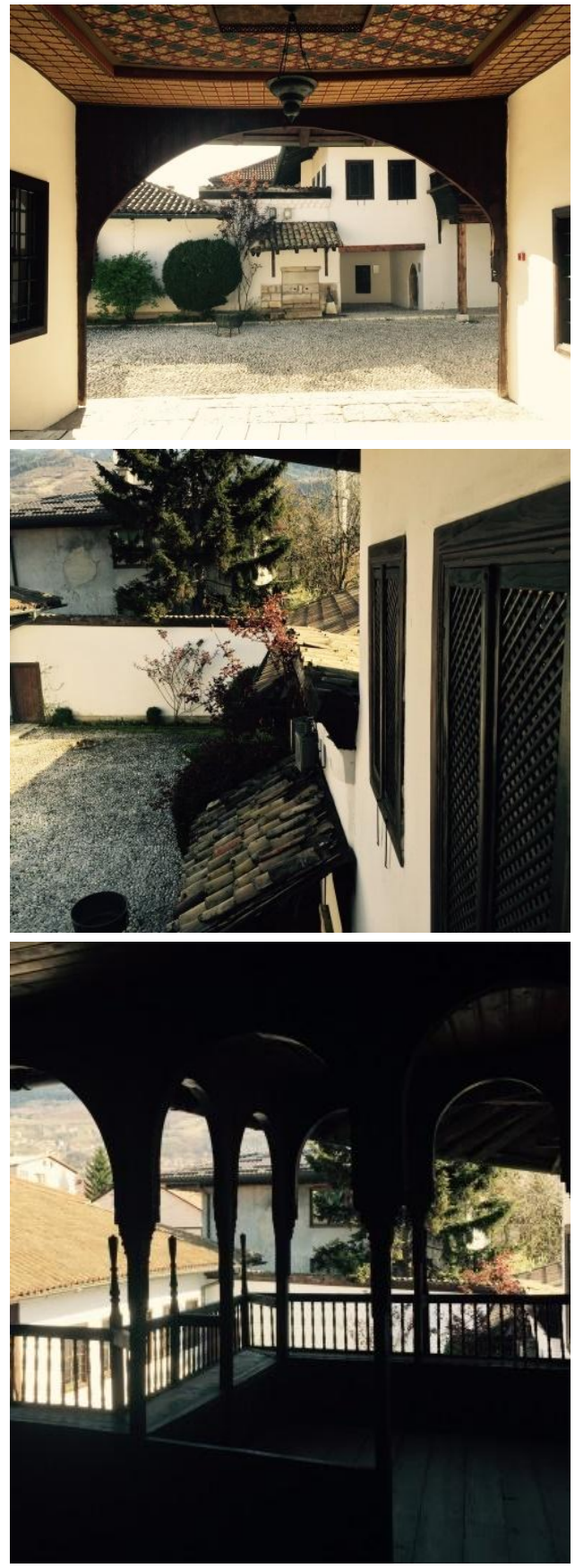

Figure 2: Interior-exterior relationship in Svrzo's house. a) Hajat in the haremluk area; b) View from divanhana; c) Divanhana and kamerija in selamluk (from left to right) 
Similarly to other cultures of the East [for example, balance between interior and exterior represents one of the main features in traditional Japanese architecture], the strict line between interior and exterior within the residential complex was blurred and replaced by a subtle transition between spatial sequences: from open to semi-open and semienclosed, to the enclosed spaces. This explains the meaning of semi-open areas (verandas) in the ground floor (hajat) and the first floor (divanhana and kamerija) and their role in establishing a gradual transition between the open space (avlija) and enclosed space (halvat): "Minimal beauty of the house can be merely grasped from the perspective of the courtyard, towards the staircases and hajat, leading to the divanhana and kamerija - areas for a life outside the room, in order to enjoy the view, not being disturbed by the neighboring houses". (Janjić-Černjavski 1975 [9]). Gradual progression of spatial sequences, from public to private, from exterior to interior, pointing towards the centre, which symbolically represents the female character, is articulated by leveling of architectural layers in traditional Bosnian house: „Just like in the case of the onion, whose interior is the deepest, the "hollow" spot from which the onion starts to germinate, the deepest part of the Bosnian house - its interior - is the soul of the house, a projection of the spiritual life of a woman leading the household, her awareness of living in this world, her family and worldly fulfillment." (Karahasan 2007, 142 [10]).

\section{Rhythm: day/night, summer/winter}

While concentrating on the time-based aspect of utilisation of space and its expressions in architectural language of the traditional Bosnian house, one realises that the traditional spaces echo the natural cycles and rhythmical alternation of day and night, and the natural shifts of seasons throughout the year. Grounded in the original Slavic model of single-volume house organised around the central hearth, the traditional house evolved under the influences of oriental philosophy and religion and gained a more complex structure. This was achieved in the process of multiplication of a the basic spatial unit called halvat, whose universal configuration enables a flexible variation of several residential functions. The multipurpose character of a halvat owes to the idea of the practical interior arrangement, reduced form and transformability of built-in equipment and a reduced number of units of movable furniture. Built-in equipment consists of musandera, dušekluk and hamamdžik, representing a unique block of elements for storage and hygiene, aligned with the entrance interior wall. On the opposite side of the room was the seating element called sećija, set along the line of the perimeter of the entire room, just below the window. The concept of maximum utilisation of the room surface and the simplicity of a typical organisation of the space enabled a rhythmical variation of residential activities during day and night, and on different occasions acting as living room, dining room and bedroom. Besides expressing the rhythm of day and night, the interior design of a traditional Bosnian house reflects the dual principle of utilisation of space throughout the summer and winter season. The change of the seasons implied the vertical zoning of the house: the ground floor was mostly made of thick masonry walls in order to be used during the winter, while the upper floor was made of the wooden structure and was mostly used during the summer time. We have seen that the core of the concept of the traditional residential architecture in Bosnia and Herzegovina essentially resonates the natural cycles such as the flow of time, changing of the seasons, shifts of the day and night. Additionally, spatial features enabling multi-functionality and transformability of the traditional spaces can be considered to be universal, timeless architectural qualities and concepts at the same time revealing the anthropocentric approach to the design of the space.

\section{Network: spatial, visual and symbolic links between selamluk and haremluk}

The contrast between private and public spaces, as the most visible articulation of the patriarchal concept of separation of male and female gender in traditional the Bosnian house, was counterweighed by a system of connections which intended to join the divided spaces.
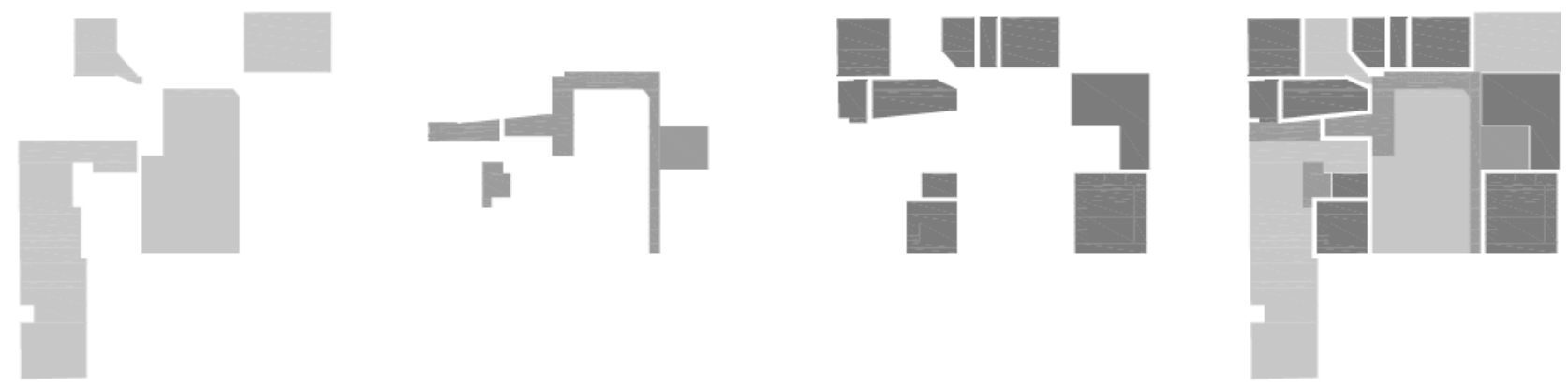

Figure 3: The schemes illustrate the relationship between open spaces, semi- enclosed and enclosed spaces in Svrzo's house 

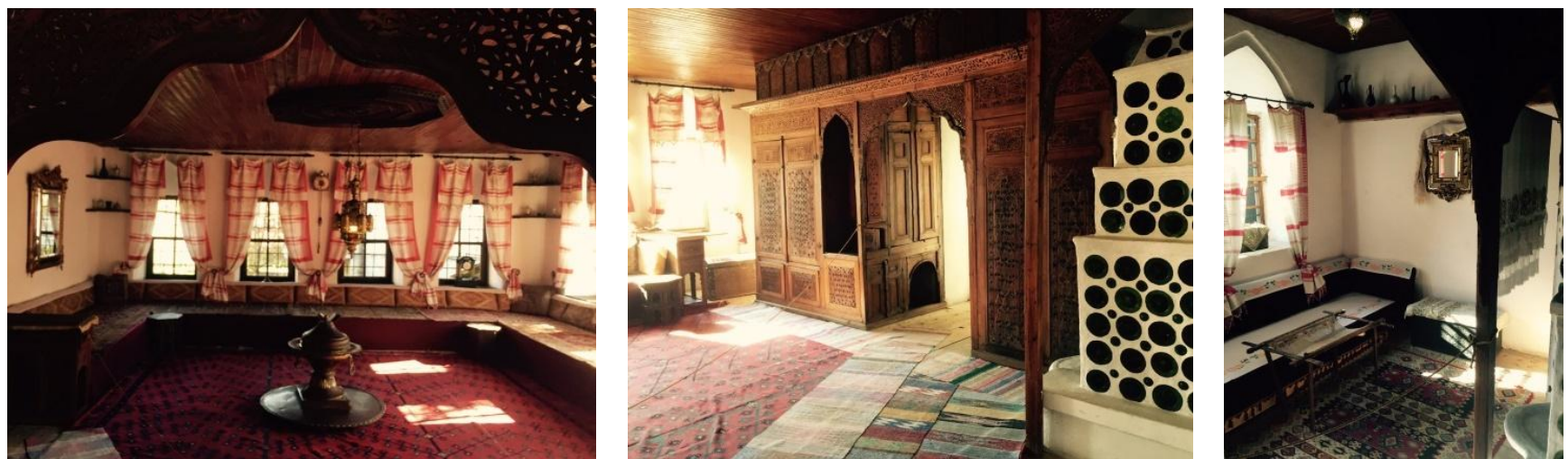

Figure 4: Svrzo's house interior. a) Grand halvat seating area; b) Musandera: multipurpose built-in interior equipment; c) Maiden's room interior (from left to right)

This section will elaborate the various forms of direct and indirect connections, including the physical, spatial, visual, tactile, acoustic and symbolic links, which acted both as deliberate and spontaneous responses to the spatial divisions within the house.

To begin with, the direct connections are represented by different types of gates (kapija), including the economic gate, men's gate, women's gate, middle gate, neighbour's gate and the small gate (kapidžik). The size and the material of the doors and gates indicated their importance. The meaning and the role of each element of connection is revealed by its unique architectural language, which is why for example, the economic gate, intended for access of guests' horse and carriage, is easily distinguishable by size, shape and material from kapidžik, small door connecting the women's courtyard and the orchard.

The logic of the communication network layout in the house is illustrated in the case of Svrzo's house, which has two key nodal points located at the very border between men's and women's premises. One of them is positioned at the intersection between main communication lines - middle gate (srednja kapija), located in the axis of the interior courtyard wall, dividing selamluk and haremluk.

The other nodal point is situated at mabejin, a hallway at the upper floor, connecting women's and men's premises. Lastly, komšipka, or the neighbor's gate, which connected orchards and gardens of adjacent houses, had a special meaning and served as an alternative means of socialisation between female members of neighbouring families.

On the other hand, there are two distinctive volumetric highlights in the overall architectural composition of the traditional Bosnian house that served as viewpoints, which actually originate from the medieval Bosnian architecture (Husedžinović 2002, 37 [11]). Their form and position express the idea of the visual connection between the house and the surrounding exterior space.

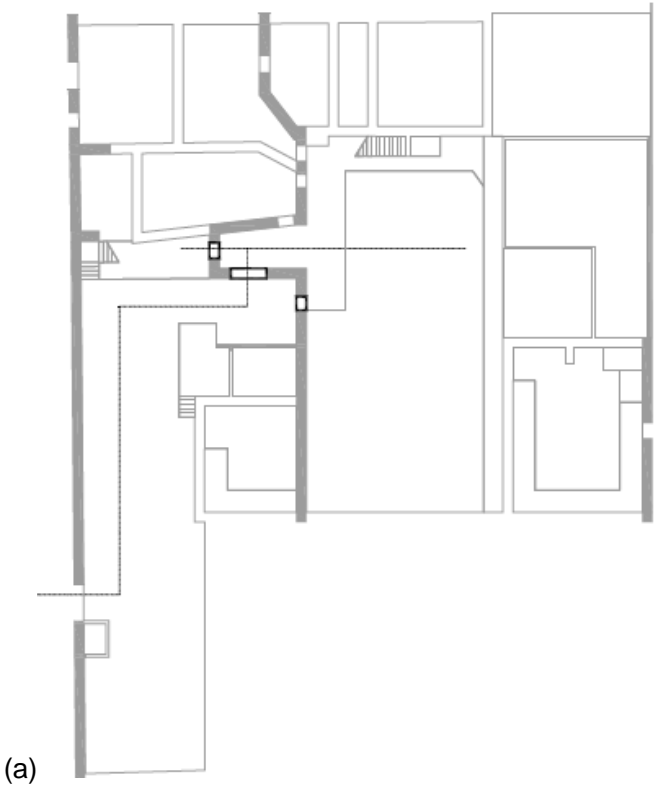

(b)

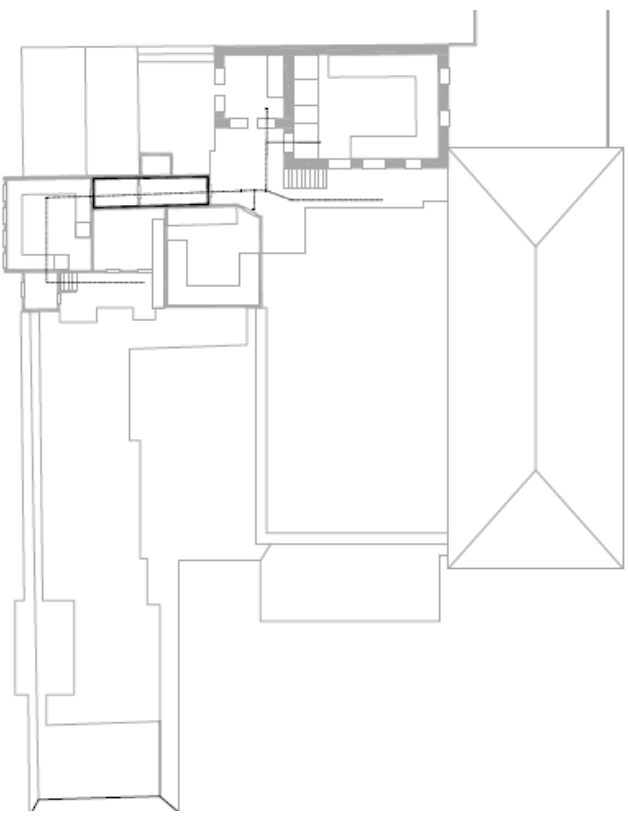

Figure 5: Connections in the Svrzo's house: middle gate in the ground floor (a) and mabejin corridor on the first floor (b) 
a)

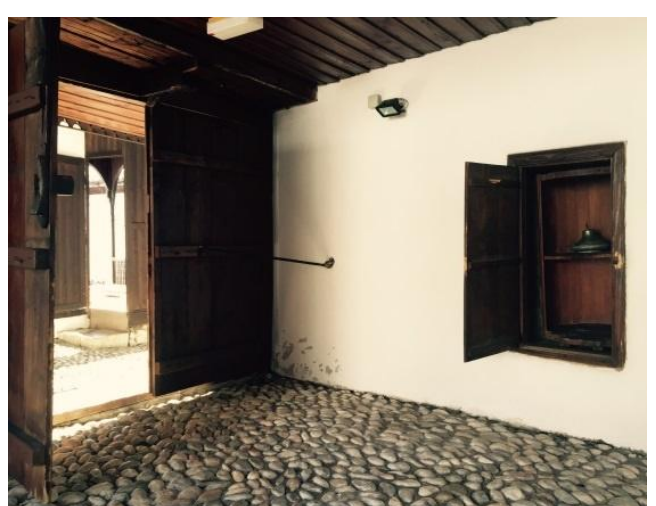

b)

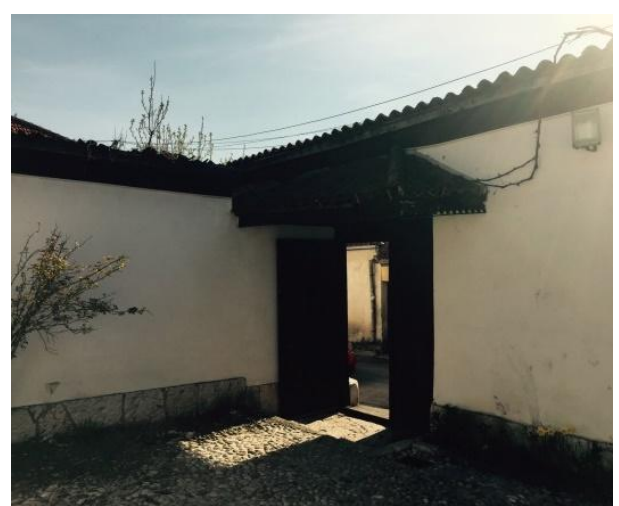

c)

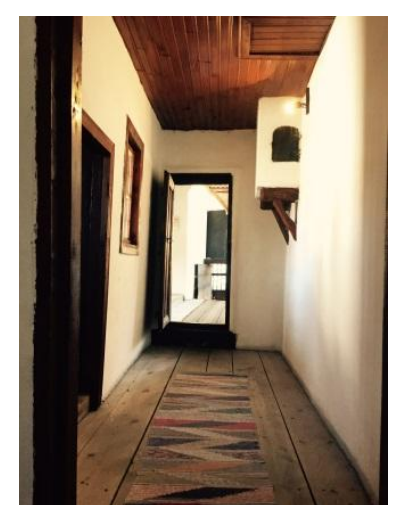

Figure 6: Connections between outside world and the house, and between selamluk and haremluk. a) Key connection point between selamluk and haremluk - Midlle gate and „čekme dolaf“; b) Main entrance gate; c) Mabejin - "in between space“ connecting selamluk and haremluk at the first floor level (from left to right)

The first element is kubećoše, a cantilevered part of selamluk, slightly protruded from the main volume in order to enable vistas to the street, and positioned in such a way to allow the same right to a view from the neighboring houses. The second viewpoint can be found inside the residential complex, as an accentuated corner of divanhana. Kamerija is a rectangular balcony, leaning towards the interior courtyard, whose poetic name suggests the idea of enjoying the inside-outside space under the moonlight.

The communication network inside the house included a special non-visual, tactile links between "men's and women's worlds". This type of connection can be recognised in the furniture element called čekme-dolaf, (Bejtić 1953, 279-280 [12]) a rotating wooden shelf, built-in the wall between selamluk and haremluk. It acted as a link in the food serving chain, between the kitchen as a part of haremluk and premises of selamluk. This was another way to conceal the women of the house from the sight of the male-guests who usually stayed at selamluk area.

Thanks to its haptic features, čekme-dolaf, as an element of built-in interior equipment, also takes part in the network of connections within the house, through establishing indirect, non-visual links between public and private areas of the house. Another way of integrating a space by non-visual means is via sound, or by acoustic links. In the case of the traditional Bosnian house, the sound of the traditional circular iron handle knocking on the wooden entrance gate, which indicated the arrival of guests (Hangi 1907, 66 [13]) can be regarded as a way to connect the space acoustically.

In addition to visual, spatial, haptic and acoustic means of connecting the two divided worlds inside the residence, there were even symbolic links that were represented by autochthonous Bosnian love songs - sevdalinkas. These songs spontaneously emanated as expressions of desire to conquer the physical barriers between the worlds of men and women: "Love stories hidden behind the closed doors, as no stranger's foot could cross their thresholds, behind tall walls and iron door handles; the life framed with flowered courtyards made up their whole maidenly worlds" (Rizvić 1969, 192 [14]).

Lastly, the analysis of symbolic links inside the traditional Bosnian house is rounded up with the representation of mother in the patriarchal culture of the Ottoman period, "heaven lies under the feet of your mother." Hadith (Indžić 2002, 264) [15].
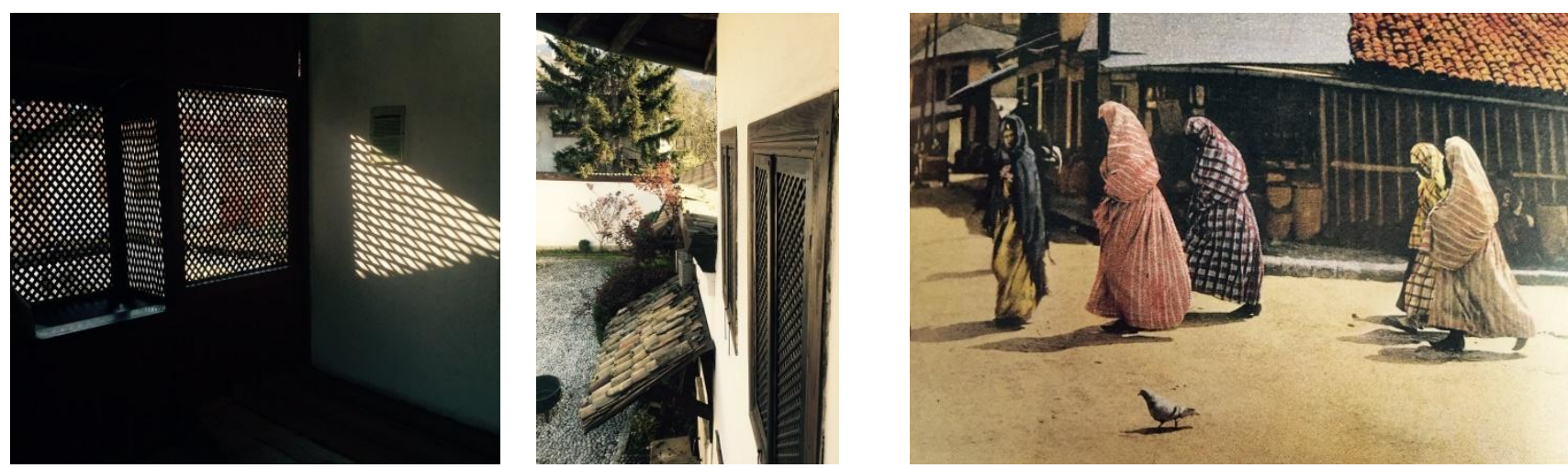

Figure 7: Visual filters: mušebak and zar. a) Mušebak - view from the interior; b) Mušebak - view from the exterior; c) Women wearing feredža and zar, traditional veils 
Mothers signified the key figures who gathered all members of the family at haremluk, which is why it can be essentially regarded as the "soul" of the house: "...proceeding to the enclosed, women's part of the house, where women and children dwell in a concealed, intimate world of love, world of sickness and child-birth, where all fears and worries vanish, where one seeks advice and consolation, where the mothers convey the first impressions of life and the world. This is where the soul of the house resides" (Karahasan 2007, 141 [10]).

\section{Conclusions}

This paper elaborated the causal relationship between the patriarchal socio-cultural value system and the architectural language of the traditional house in Bosnia-Herzegovina and particularly focused on the gender criterion of the separation of the residential space. According to the predefined objective and the scope of research, this paper did not include the cultural qualifications of the status of women in the traditional society. Instead, it focused on the analysis of architectural principles and elements of the composition of traditional space, as expressions of particular traditional cultural concepts as well as the interpretation of their meanings and architectural qualities from the contemporary perspective. The thesis was developed from the concept of a traditional home as the artifact of patriarchal culture, as well as from the consideration of female identity as the key determining factor that defined the distinctive architectural language and spatial organisation of traditional house in Bosnia and Herzegovina.

This study has shown that the crucial four principles related to the patriarchal concept of separation of gender through space have led to a specific architectural expression in traditional residential architecture in Bosnia and Herzegovina. Original connotation of the principle of contrast between public and private sphere lies in the separation of male and female gender in family and society.

The principle of contrast is reflected in the ambiguous dual concept of the house and can be identified by the visual opposition of the enclosed character of the exterior image of the house and the richness of the interior atmosphere of the residential complex. This particular architectural feature of ambiguity, established through binary opposition of men's and women's part of the house, would not be attainable in a case of exclusion of either polarity. Another significant principle of composition of the traditional Bosnian house is the principle of balance between the building and its natural surroundings, which was originally related to religious and cultura values. Since the patriarchal society imposed the limitations of movement of women in public space, the principle of symbiosis of exterior and interior, between built and natural environment is primarily envisioned as a simulation of micro cosmos for the female members of the family who spent most of the time inside the residential complex.

In the case of the traditional Bosnian house, the theoretical rigidity of the principle of contrast was counterbalanced with subtle spatial layering, or gradation of spatial sequences, from public, semiprivate to the private sphere, and from open and semi-closed to enclosed space. Since the patriarchal society assigned women the role of dedication to family life, therefore their domestic spaces as their micro cosmos and were designed in a flexible manner, with rooms that enabled cyclic modification of different residential activities within the same space. Multifunctional and flexible approach to the design of interior layout and equipment primarily responded to the functional needs for a rational spatial organisation. In addition, the resulting architectural language and transformable character of the space reflected the natural cycles of life, the shifts of the day and night, the change of the seasons.

Table 2: Analysis and interpretation of architectural language of the traditional residential architecture in Bosnia and Herzegovina

\begin{tabular}{|c|c|c|c|c|c|}
\hline \multirow{3}{*}{ 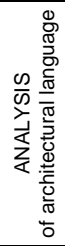 } & Principle & Contrast & Balance & $\begin{array}{l}\text { Rhythm } \\
\end{array}$ & Network \\
\hline & Level & $\begin{array}{l}\text { Public/Private } \\
\text { Male/Female }\end{array}$ & $\begin{array}{l}\text { Exterior/Interior } \\
\text { Human being/Space }\end{array}$ & $\begin{array}{l}\text { Day/Night } \\
\text { Summer/Winter }\end{array}$ & $\begin{array}{l}\text { Direct/Indirect links } \\
\text { Physical/Spatial/ } \\
\text { Visual/Tactile/Acoustic/Symbolic links }\end{array}$ \\
\hline & $\begin{array}{l}\text { Space/ Element/ } \\
\text { Form// } \\
\text { Symbol }\end{array}$ & $\begin{array}{l}\text { Selamluk/Haremluk } \\
\text { Wall } \\
\text { "Men's world" /"Women's world" }\end{array}$ & $\begin{array}{l}\text { Halvat } \\
\text { Divanhana/Hajat } \\
\text { Interior courtyards } \\
\text { Orchard }\end{array}$ & $\begin{array}{l}\text { Mobile furniture } \\
\text { Built-in furniture } \\
\text { Flexible interior layout } \\
\text { Rational spatial organisation }\end{array}$ & $\begin{array}{l}\text { Gates/Doors/Windows/Mabejin } \\
\text { Čekme } \\
\text { dolaf/Iron door handle } \\
\text { Kube-ćoše/Kamerija } \\
\text { Mušebak/Zar } \\
\text { Sevdalinka/Mother figure } \\
\end{array}$ \\
\hline \multirow{2}{*}{ 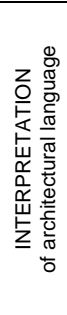 } & $\begin{array}{l}\text { Original meaning/ } \\
\text { Cultural symbolism }\end{array}$ & $\begin{array}{l}\text { Patriarchal concept of gender } \\
\text { roles } \\
\text { The role of women-oriented } \\
\text { towards private sphere and family } \\
\text { The role of men oriented towards } \\
\text { work and public sphere }\end{array}$ & $\begin{array}{l}\text { Courtyard and garden as response } \\
\text { to limited movement of women in } \\
\text { public space } \\
\text { Building-nature relationship } \\
\text { Idea of a house as a micro } \\
\text { cosmos }\end{array}$ & $\begin{array}{l}\text { Space as a simulation of } \\
\text { micro cosmos } \\
\text { Space as a reflection of } \\
\text { natural life cycle }\end{array}$ & $\begin{array}{l}\text { Expression of socio-cultural values } \\
\text { Definition of family roles } \\
\text { Regulation of social relations }\end{array}$ \\
\hline & $\begin{array}{l}\text { Contemporary } \\
\text { meanings/ } \\
\text { Architectural qualities }\end{array}$ & $\begin{array}{l}\text { Contrast btw exterior form and } \\
\text { interior atmosphere } \\
\text { Introverted architectural form } \\
\text { Space within space } \\
\text { Dual house } \\
\text { Contrast btw exterior and interior } \\
\text { image }\end{array}$ & $\begin{array}{l}\text { Subtle transition of spatial } \\
\text { sequences: from exterior to interior } \\
\text { space } \\
\text { Layered spaces } \\
\text { Interaction of natural and } \\
\text { built/artificial elements }\end{array}$ & $\begin{array}{l}\text { Multifunctional interior } \\
\text { furnishings } \\
\text { Flexibility and transformability } \\
\text { of space } \\
\text { Human scale design }\end{array}$ & $\begin{array}{l}\text { The right to a view } \\
\text { Deliberate and spontaneous } \\
\text { connections of the separated spaces } \\
\text { Poetic and multisensory qualities of } \\
\text { interior spaces }\end{array}$ \\
\hline
\end{tabular}


Lastly, parallel to the concept of gender differentiation of space, the traditional design encompassed a particular network of connections and communications, which were developed strategically as well as spontaneously and served to unify the entire architectural composition. The network of direct and indirect communications between the split spaces in the house include the physical, spatial, visual, tactile, acoustic and symbolic links. Originality and artistic qualities of these links, as in the case of the love song - sevdalinka, can be regarded as a sincere human reaction to the imposed cultural constructs, such as were the spatial barriers in traditional homes.

A contemporary interpretation of the architectural language of the traditional Bosnian house from the perspective of the gender-based differentiation space has indicated that the idiosyncratic architectural expression has actually been derived from the influence of the female identity within the framework of the patriarchal culture. Essentially, the concept of spatial division and barriers in the traditional Bosnian house can be perceived as an architectural tool used by the patriarchal society which would designate women only to the family sphere, while excluding them from the public life. As a response to the ideological guidelines, architectural language was enriched by valuable spatial, design, artistic and lyric phenomena, which raised architectural qualities of the traditional house to a new level. Some of the created values that were in fact explicitly or implicitly influenced by the female figure within the patriarchal cultural framework include several architectural qualities, such as: dual spatial concepts, architectural layering, gradation of spatial sequences, correlation of built and natural environment, authentic architectural and interior forms and ambiences, and finally, poetics of the space which echoes the metaphor of secrecy of the female figure. Even though patriarchal society strived to conceal it, female identity starkly emerged and crafted implicit, symbolic traces and forms, while essentially contributing to the singularity of the cultural, especially the architectural heritage of Bosnia and Herzegovina.

\section{References}

1. Wigley M. Untitled: The Housing of Gender. In Sexuality and Space, edited by Beatriz Colomina, 334. Princeton Architectural Press, 1996.

2. Ian M. Archeology and Gender Ideologies in Early Archaic Greece. Transactions of the American Philological Association (Transactions of the American Philological Association, Stanford University). 1999; 129: 306.

3. Mulvey L. Fetishism and Curiosity. Bloomington: Indiana University Press, 1996.

4. Younis H. Skice porodičnog života u Sarajevu posljednjih decenija osmanske vladavine. Prilozi Instituta za istoriju. 2007; 36: 38.
5. Spahić-Šiljak Z. Ženska ljudska prava - islamska perspektiva. In Ljudska prava žena, 87. Zagreb: Institut društvenih znanosti, 2011.

6. Spahić-Šiljak Z. Žene, religija i politika: Analiza utjecaja interperativnog religijskog naslijeđa judaizma, kršćanstva i islama na angažman žene u javnom životu i politici u BiH. Sarajevo: IMIC Zajedno, 2007.

7. Spahić-Šiljak Z, Anić RJ. Žene, religija i politika, Analiza uticaja interpretativnog religijskog naslijeđa judaizma, kršćanstva i islama na angažman žene u javnom životu i politici u $\mathrm{BiH}$. Sarajevo: TPO Fondacija - CIPS Univerziteta u Sarajevu, 2009.

8. Roskiewicz J. Studien uber Bosnien und die Herzegovina. Leipzig, Wien: Brockhaus Verlag, 1868.

9. Janjić-Černjavski Z. Stambena kultura starog Sarajeva. Sarajevo: Muzej grada Sarajeva, 1975.

10. Karahasan D. Izvještaji iz tamnog vilajeta. Sarajevo: Dobra knjiga, 2007.

11. Husedžinović S. Nastanak i razvoj Svrzine kuće. In Svrzina kuća (monografija), 37. Sarajevo: Muzej Sarajeva, 2002.

12. Bejtić A. Spomenici Osmanlijske arhitekture u Bosni i Hercegovini. Prilozi za orijentalnu filologiju i istoriju jugoslovenskih naroda pod turskom vladavinom V. 1953: 279-280.

13. Hangi A. Život i običaji muslimana u Bosni i Hercegovini. II. Sarajevo: Naklada Danijela A. Kajona, 1907.

14. Rizvić M. O lirsko-psihološkoj strukturi sevdalinke. Sarajevo, 1969

15. Indžić S. Zbirka Poslanikovih hadisa. Sarajevo: Libris, 2002.

\section{Glossary}

Avlija (avliya), interior courtyard in traditional Bosnian houses.

Čekme-dolaf, a rotating wooden shelf, built-in the wall between selamluk and haremluk.

Divanhana (diwanhana), a semi-open space (porch, veranda) in oriental houses.

Dušekluk, a part of musandera; storage for linen.

Feredža, zar traditional veils worn by muslim women.

Hajat (hayat), a semi-open space (porch, veranda) located at the ground floor in traditional Bosnian houses.

Halvat (halwat), room, multipurpose living area.

Hamamdžik, a part of musandera; traditional form of shower.

Haremluk, private/women's quarters in traditional Bosnian houses.

Kamerija (qamaria), a part of divanhana; rectangular balcony, leaning towards the interior courtyard.

Kapidžik, a small gate.

Kapija, a gate.

Komšipka, a neighbor's gate.

Kube-ćoše, a cantilevered part of selamluk.

Mabejin, a hallway at the upper floor, connecting 
women's and men's premises.

Musandera, traditional Ottoman multipurpose built-in interior equipment.

Mušebak, wooden lattice covering the windows and enabling vistas only in one direction.

Sećija, a seating element, set along the line of the perimeter of the entire room, just below the window.

Selamluk, public/men's quarters in traditional Bosnian houses.

Sevdalinka, the traditional Bosnian loves song. Sevdalinka originates from the Turkish word sevdah, meaning love and longing.

Vilajet (Vilayet), a province in the Ottoman empire. 